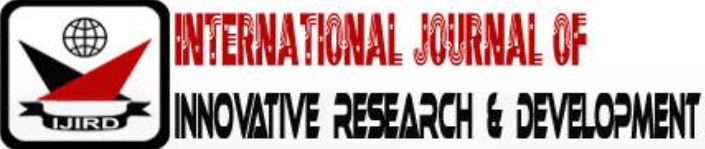

ISSN 2278 - 0211 (Online)

\section{Safety Practices in the Oil and Gas Industries of the Nigerian Petroleum Sector}

Obiorah, Cynthia Amaka R.
Ph.D. Student, Centre for Occupational Health and Safety, Institute of Petroleum Studies.
University of Port Harcourt, Nigeria
Oyegun, Charles U.
Professor, Department of Geography and Environmental Management
University of Port Harcourt, Nigeria
Dr. Ugbebor, John N.
Senior Lecturer, Department of Civil and Environmental Engineering
University of Port Harcourt, Nigeria

\begin{abstract}
:
The objective of this study was to determine the current safety practices in the oil and gas firms of the Nigerian petroleum sector. The study adopted a cross sectional research design and sampling 373 employees from the upstream, midstream and downstream sectors of the industry. The main instrument for data collection was the structured questionnaire. Systematic sampling was adopted in the administration of the questionnaireswith the aid of a 5-point Likert scale. IBM Statistical Package for Social Sciences was employed in analysis of the data. The result of the educational qualification of the employees showed that 50(13\%) had diploma, 168(45\%) had first degree, 120(32\%) had master's degree while 35(10\%) employees had $\mathrm{PhD}$. Most of the employees were from the midstream sector (50.9\%) followed by the downstream sector (26.3\%) and the upstream sector $(22.8 \%)$ respectively. The ranking of Safety practices showed that organizational safety policy ranked 1 st followed by management commitment $\left(2^{\text {nd }}\right)$ the safety inspections and safety communication. However, Safety training/retraining and employee incentive/ reward ranked $5^{\text {th }}$ and $6^{\text {th }}$ respectively. A strong positive correlation $(\mathrm{r}=0.842)$ which was statistically significant at $(\mathrm{p}=0.045)$ was observed between educational qualification of the employees and the safety compliance. While safety practices are observed in the oil and gas firms in Nigeria as demonstrated by the study, it is strongly recommended that routine safety assessment should be carried out by firms with a view to receiving recommendations from employees on how to improve the safety culture of the firms in all upstream, midstream and downstream sectors while safety compliant employees should be motivated through rewards and incentives.
\end{abstract}

Keywords: Safety Practices, Nigeria, Oil and gas firms

\section{Introduction}

Nigeria is the largest oil producer in Africa, holds the largest natural gas reserves on the continent, and is among the world's top five exporters of liquefied natural gas (LNG). In 2011 there were 37.2 billion barrels of proven oil reserves in Nigeria, producing about 2.4 million barrels per day (bbl/ d), ranking the country as the largest oil producer in Africa and the 11th largest in the world. The country's oil and natural gas industry typically accounts for $75 \%$ of government revenue and $90 \%$ of total export earnings (Cooke \& Goldwyn, 2015).

The Nigerian Oil and gas industry can be categorized into three main sub-sectors, namely, upstream, midstream and downstream sectors (Monday, Ekperiware, \& Muritala, 2016). The upstream sector covers all the activities leading to the exploration and drilling of crude oil, while the downstream sector covers the processing of crude oil, its distribution as well as sales. In other words, the downstream oil industry is the business of importing, exporting, re-exporting, shipping, transporting, processing, refining, storing, distributing, marketing and/ or selling, crude oil, gasoline, diesel, liquefied petroleum gas, kerosene, and other petroleum and crude oil products (Clews, 2016b, 2016a; Persaud, Kumar, \& Kumar, 2003).

Oil and gas industries (both onshore and offshore) carry out operations that pose high risk levels. Many of these industries have experienced accidents due to poor safety culture/ safe work operating procedures (Avwiri, Enyinna, \& Agbalagba, 2007). These occupational injuries and ill health create an economic and human burden, which forms a major concern. The international labour organization (ILO) showed that 321,000 people are fatally injured every year due to workplace related injuries. Addressing this challenge requires a group effort by the workers, employers and government to build, implement and continuously strengthen a preventive health and safety culture (ILO, 2013; Takala et al., 2014). 
Notably, safety and health risks lurk across all levels of the industry including production projects, facility operations, maintenance, construction, transport, storage, and during the application of the oil derived products. Moreover, the huge volumes of materials that are processed, handled or used exacerbates any accident situation in the industry (Achaw \& Boateng, 2012). In more specific terms, the hazards and risks faced by employees of the oil and gas industries includes; chemical hazards (toxic, corrosive, irritant and sensitizing substances and possible carcinogens); physical hazards (noise, vibration, various forms of radiation, thermal extremes); biological hazards (legionella, food poisoning); ergonomic hazards (manual handling activities, workstations, VDUs); and psychosocial hazards associated with either the work (overload, underload, hours of work, tour patterns, work relationships, etc.) or the location (travel, being away from home, living on the job, etc.) (Gardner, 2003).

In view of this, the study was carried out to ascertain the different safety practices carried out in thethree different sectors (upstream, mid-stream and downstream) of the Nigerians petroleum industry. Since the petroleum industry is a safety critical organization (SCO) with hazardous settings, environment and practices, the potential for accident and injuries remains very high (Guldenmund, 2000; Hystad, Bartone, \&Eid, 2014). Therefore, determining the employee safety practices of the industries with a view to identifying areas of improvements on the part of the employees is a key rationale for carrying out this study.

\section{Objectives of the Study}

- To determine the current safety practices in the oil and gas industries of the Nigerian petroleum sector.

- To determine the relationship between educational qualification and safety compliance in the oil and gas industries of the Nigerian petroleum sector.

\section{Methodology}

This study covered selected oil and gas firms operating in the upstream, midstream and downstream sectors of the Nigerian petroleum industry. The study adopted a cross sectional research design using the survey method. The systematic sampling was adopted in the administration of the questionnaires. A sample size of 387 determined using TaroYamane's equation. Primary data were sourced from the volunteer participants (employees) from the oil and gas firms. The questionnaire was the main instrument for data collection. It was structured to contain closed ended questions. A 5point modified Likert scale was adopted in the present study. This modified Likert scale was used to solicit responses from the respondents. Quantifiers were assigned to points in the continuum as; Strongly Agree $(\mathrm{SA})=5$, Agree $(\mathrm{A})=4$, Disagree $(D)=3$, Strongly Disagree $(S D)=2$ and Undecided $(U)=1$. These scores were then multiplied by the number of responses and divided by the total number of respondents to determine the weighted score and percentages calculated because those who strongly agree and agree are saying the same thing. The IBM Statistical Package for Social Sciences (SPSS) version 21 was employed in the analysis of the data. Data were analyzed using descriptive (mean and ranks) and inferential statistical techniques (Pearson Product Moment Correlation (PPMC)).

\section{Results}

\begin{tabular}{|c|c|c|}
\hline Education & Frequency & Percentage (\%) \\
\hline Diploma & 50 & 13 \\
\hline First degree & 168 & 45 \\
\hline Masters & 120 & 32 \\
\hline PhD and others & 35 & 10 \\
\hline Total & 373 & 100 \\
\hline
\end{tabular}

Table 1: The Educational Qualification of the Respondents Source: Field Survey, 2018

The distribution of findings with respect to respondent's educational levels is indicated on Table 1. Employees with diploma accounted for 50 (13\%) of the respondents. First degree (B. Sc.) holders were 168 representing $45 \%$ of the sample drawn for the study. It was found that 120 (32\%) of Oil and gas sector staff studied had obtained their master's degrees while 35 (10\%) of the respondents had $\mathrm{PhD}$. 


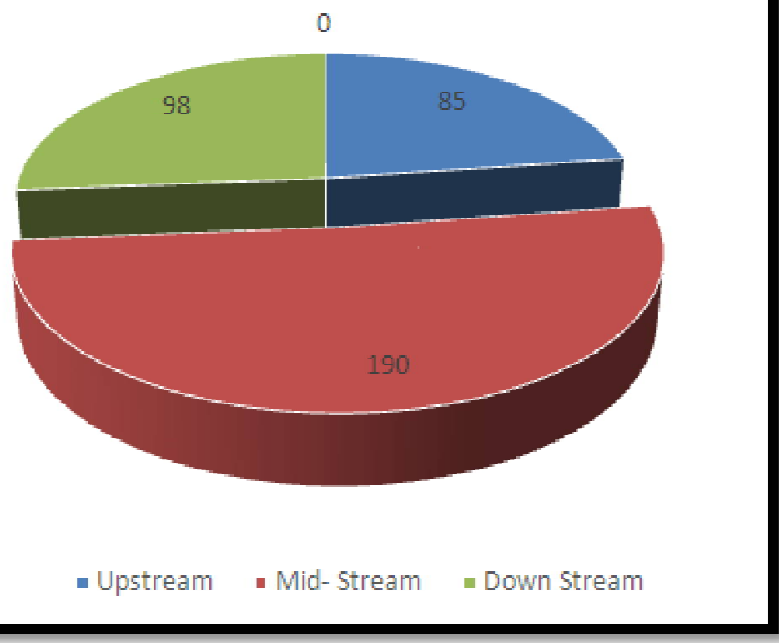

Figure 1: Oil and Gas Sector of Employee Attachment

The employee sector of employment is shown in figure 1. From the response, $85(22.8 \%)$ employees were attached to the upstream sector while 190(50.9\%) and 98(26.3\%) of the employees were attached to the mid-stream and downstream sectors.

\begin{tabular}{|c|c|c|c|c|c|c|c|c|c|c|}
\hline $\mathbf{S} / \mathbf{N}$ & $\begin{array}{l}\text { Current Safety } \\
\text { Practices } \\
\text { available in the } \\
\text { Oil and Gas } \\
\text { Sector }\end{array}$ & $\begin{array}{l}\text { SA } \\
{[5]}\end{array}$ & $\begin{array}{c}\mathrm{A} \\
{[4]}\end{array}$ & $\begin{array}{c}\text { D } \\
{[3]}\end{array}$ & $\begin{array}{l}\text { SD } \\
{[2]}\end{array}$ & $\begin{array}{c}\mathrm{U} \\
{[1]}\end{array}$ & $\begin{array}{c}\text { Total } \\
\text { Responses }\end{array}$ & $\begin{array}{c}\text { Weighted } \\
\text { Mean }\end{array}$ & Rank & Remark \\
\hline 1 & $\begin{array}{l}\text { Organizational } \\
\text { Safety Policy }\end{array}$ & $\begin{array}{c}700 \\
(49.6)\end{array}$ & $\begin{array}{c}444 \\
(31.5)\end{array}$ & $\begin{array}{l}123 \\
(8.7)\end{array}$ & $\begin{array}{l}126 \\
8.9)\end{array}$ & $\begin{array}{c}17 \\
(1.2)\end{array}$ & 1410 & 3.78 & $1^{\text {st }}$ & Agreed \\
\hline 2 & $\begin{array}{c}\text { Management } \\
\text { Commitment to } \\
\text { Safety }\end{array}$ & $\begin{array}{c}440 \\
(33.0)\end{array}$ & $\begin{array}{c}592 \\
(44.4)\end{array}$ & $\begin{array}{c}150 \\
(11.3)\end{array}$ & $\begin{array}{l}112 \\
8.4)\end{array}$ & $\begin{array}{c}38 \\
(2.9)\end{array}$ & 1332 & 3.57 & $2^{\text {nd }}$ & Agreed \\
\hline 3 & $\begin{array}{c}\text { Safety } \\
\text { Inspections }\end{array}$ & $\begin{array}{c}560 \\
(42.3)\end{array}$ & $\begin{array}{c}392 \\
(29.6)\end{array}$ & $\begin{array}{c}201 \\
(15.2)\end{array}$ & $\begin{array}{c}150 \\
(11.3)\end{array}$ & $\begin{array}{c}21 \\
(1.6)\end{array}$ & 1324 & 3.55 & $3^{\text {rd }}$ & Agreed \\
\hline 4 & $\begin{array}{c}\text { Safety } \\
\text { communication }\end{array}$ & $\begin{array}{c}435 \\
(34.6)\end{array}$ & $\begin{array}{c}384 \\
(30.5)\end{array}$ & $\begin{array}{c}264 \\
(20.9)\end{array}$ & $\begin{array}{c}146 \\
(11.6)\end{array}$ & $\begin{array}{c}29 \\
(2.3)\end{array}$ & 1258 & 3.37 & $4^{\text {th }}$ & Agreed \\
\hline 5 & $\begin{array}{l}\text { Safety training } \\
\text { \& retraining }\end{array}$ & $\begin{array}{c}380 \\
(32.6)\end{array}$ & $\begin{array}{c}324 \\
(27.8)\end{array}$ & $\begin{array}{c}252 \\
(21.6)\end{array}$ & $\begin{array}{c}154 \\
(13.2)\end{array}$ & $\begin{array}{c}55 \\
(13.2)\end{array}$ & 1165 & 3.12 & $5^{\text {th }}$ & Agreed \\
\hline 6 & $\begin{array}{c}\text { Employee } \\
\text { incentive \& } \\
\text { reward }\end{array}$ & $\begin{array}{c}270 \\
(23.4)\end{array}$ & $\begin{array}{c}292 \\
(25.3)\end{array}$ & $\begin{array}{c}384 \\
(33.2)\end{array}$ & $\begin{array}{c}182 \\
(15.8)\end{array}$ & $\begin{array}{c}27 \\
15.8)\end{array}$ & 1155 & 3.10 & $6^{\text {th }}$ & Agreed \\
\hline & $\begin{array}{c}\text { Criterion Mean } \\
=3.00\end{array}$ & & & & & & & & & \\
\hline
\end{tabular}

Table 2: Current Safety Practices in the Oil and Gas Industries

Source: Researchers Field Work, 2018

$$
\begin{gathered}
\text { Scale: } \quad 0-1.99=\text { Undecided } \\
2.00-2.99=\text { Disagreed } \\
3.00-5.00=\text { Agreed }
\end{gathered}
$$

N/ B Values In Parenthesis () Are Percentages

Table 2 showsthe current safety practices in selected companies in the Nigerian petroleum industry and perceived responses from their employees. Notably, it was also observed that among these safety practices listed, Organizational Safety Policy was perceived as the most dominant safety practice practiced in the selected companies in the Nigerian petroleum industry when compared to other safety practices as it ranked 1st with an average of 3.78 on a scale of 1-5. It was followed by management commitment to safety (3.57), Safety Inspections (3.55), Safety communication (3.37), Safety training \& retraining (3.12) and Employee incentive \& reward (3.10). 


\begin{tabular}{|c|c|c|c|c|c|c|c|}
\hline & \multicolumn{5}{|c|}{ Compliance To Safety } & \multirow[t]{2}{*}{ Total } \\
\hline & & Undecided & $\begin{array}{c}\text { Strongly } \\
\text { Disagreed }\end{array}$ & Disagreed & Agreed & $\begin{array}{l}\text { Strongly } \\
\text { Agreed }\end{array}$ & \\
\hline \multirow{4}{*}{$\begin{array}{l}\text { Educational } \\
\text { Qualification }\end{array}$} & Diploma & $7(20 \%)$ & $5(14 \%)$ & $9(26 \%)$ & $10(29 \%)$ & $4(11 \%)$ & $35(9.4 \%)$ \\
\hline & $\begin{array}{c}\text { First } \\
\text { Degree }\end{array}$ & $38(22 \%)$ & $38(23 \%)$ & $22(13 \%)$ & $32(19 \%)$ & $38(23 \%)$ & $168(45.0 \%)$ \\
\hline & Masters & $21(13 \%)$ & $39(24 \%)$ & $22(14 \%)$ & $41(26 \%)$ & $37(23 \%)$ & $160(42.9 \%)$ \\
\hline & Ph.D & $1(10 \%)$ & $3(30 \%)$ & $2(20 \%)$ & $3(30 \%)$ & $1(10 \%)$ & $10(2.7 \%)$ \\
\hline \multicolumn{2}{|c|}{ Tota } & $67(18 \%)$ & $85(23 \%)$ & $55(15 \%)$ & $86(23 \%)$ & $80(21 \%)$ & $373(100 \%)$ \\
\hline
\end{tabular}

Table 3: Frequency of Response on of Educational Qualification on Compliance to Safety

Source: Researchers Field Work, 2018

Table 3 shows the frequency of response to safety compliance based on educational qualification.

Notably, out of 35 diploma holders, $29 \%$ agreed that educational qualification has an impact on compliance to safety culture, 23\% first degree holders strongly agreed to the view, 26\% master's degree holders concurred while $30 \% \mathrm{PhD}$ holders agreed to this view. In general out of 373 respondents $23 \%$ agreed, $21 \%$ strongly agreed, $23 \%$ strongly disagreed, and $18 \%$ were undecided whereas $15 \%$ disagreed.

These views were further subjected to statistical test to determine if there was any relationship between educational qualification and compliance to safety culture using Pearson Rho Moment Correlation Coefficient.

\begin{tabular}{|c|c|c|c|}
\hline \multicolumn{2}{|c|}{} & $\begin{array}{c}\text { Educational } \\
\text { Qualification }\end{array}$ & Safety Compliance \\
\hline \multirow{3}{*}{ Educational Qualification } & Pearson Correlation & 1 & $.842^{*}$ \\
\cline { 2 - 4 } & Sig. (2-tailed) & & .045 \\
\cline { 2 - 4 } & $\mathrm{N}$ & 373 & 373 \\
\hline \multirow{2}{*}{ Safety Compliance } & Pearson Correlation & $.842^{* *}$ & 1 \\
\cline { 2 - 4 } & Sig. (2-tailed) & .045 & 373 \\
\cline { 2 - 4 } & $\mathrm{N}$ & 373 & \\
\hline
\end{tabular}

Table 4: Correlation of Educational Qualification versus Safety Compliance

*. Correlation Is Significant at the 0.05 Level (2-Tailed)

The Correlation table 4 shows that there is a positive correlation between educational qualification and safety compliance of oil workers as expressed through the respondents assessment. A positive correlation $(r=0.842)$ and a $p$ value of 0.045 was obtained. This is an indication that education can affect the behaviours and response of the employees to laid down safety rules and policies thereby influencing their compliance to safety.

\section{Discussion}

Safety practices are clear procedures established by the management of a firm or by regulators of industries with the sole aim of preventing accidents, risks and hazards. These practices vary from industry to industry (Nangih, 2017). Results of the study agreed on management commitment to safety, a typical characteristics of safety managers in Africa as suggested by (Aran\d jelović, Stanković, \& Nikolić, 2006; Emenike, 2013; Udotong, 2015). Notably, this finding follows similar conclusion from a study of 157 oil and gas offshore employees (O'Dea \& Flin, 2001). This finding agrees with studies and reports by Dorman (2000b) and Mossink \& de Greef, (2002) which emphasized in their study that most safety managers are aware of what to do but for some reasons either financial, or a lack of the will power to enforce of both they just refuse to enforce actual safety procedures at work place.

Some reported safety practices in the oil and gas firms includes; availability of alarms systems, use of PPEs, housekeeping, safety information communication, emergency assembly points, visitor safety training, integrity of equipment, availability of first aid kit, provision of firefighting equipment, dedicated safety officers, ignition control systems and detection systems (Achaw \& Boateng, 2012).

The respondents suggested that the workers need to combine education qualification with that of safety training to be safety conscious. This idea has also been corroborated by Falkenburg \& Schyns (2007) who have suggested that only education qualification does not translate to safety consciousness but that rather, frequent safety training is required to build effective safety culture. According to Fang et al. (2006) education remains pertinent to improved safety culture and climate in a work environment.

Implementing adequate safety cultural practices results in benefits such as; increased productivity, loss of assets, reduced downtime, workers compensation claims and improved employee morale. In all, the smooth running of the highrisk oil and gas operations is dependent on the implementation of good safety practices. 


\section{Conclusion}

Adequate implementation and adoption of necessary safety practices in the Nigerian oil and gas firms remains indispensable to the success, growth and performance of such firms. It will also ensure the preservation of lives and assets of such firms. Findings indicate the presence of safety practices in the oil and gas industries in the Nigerian petroleum sector. There is dire need for improvement in aspects of safety communication, training and retraining and the provision of rewards and incentives especially to safety compliant employees. It is recommended therefore that routine safety assessment should be carried out by firms with a view to receiving recommendations from employees on how to improve the safety culture of the firms in all upstream, midstream and downstream sectors.

\section{References}

i. Achaw, O.-W., \&Boateng, E. D. (2012). Safety practices in the oil and gas industries in Ghana. International Journal of Development and Sustainability 1 (2), 456-465.

ii. Arandelović, M., Stanković, S., \&Nikolić, M. (2006). Workplace health promotion: Quality criteria. FactaUniversitatis-Series: Working and Living Enviromental Protection, 3(1), 27-33.

iii. Avwiri, G. O., Enyinna, P. I., \&Agbalagba, E. O. (2007). Terrestrial radiation around oil and gas facilities in Ughelli Nigeria. Journal of Applied Sciences, 7(11), 1543-1546.

iv. Clews, R. J. (2016a). Chapter 8 - Pipelines, Storage and Other Infrastructure. In R. J. Clews (Ed.), Project Finance for the International Petroleum Industry (pp. 137-152). https:/ / doi.org/ 10.1016/ B978-0-12-800158-5.00008-6

v. Clews, R. J. (2016b). Introduction. In R. J. Clews (Ed.), Project Finance for the International Petroleum Industry (pp. ix-xi). https:// doi.org/ 10.1016/ B978-0-12-800158-5.00027-X

vi. Cooke, J. G., \& Goldwyn, D. L. (2015). Africa's New Energy Producers: Making the Most of Emerging Opportunities. Rowman\& Littlefield.

vii. Dorman, P. (2000). The economics of safety, health, and well-being at work: an overview. ILO Geneva.

viii. Emenike, G. C. (2013). OCCUPATIONAL HEALTH AND SAFETY IN THE OIL AND GAS INDUSTRY IN NIGERIA Monday OhiAsikhia and. 11(2).

ix. Falkenburg, K., \&Schyns, B. (2007). Work satisfaction, organizational commitment and withdrawal behaviours. Management Research News, 30(10), 708-723. https:/ / doi.org/ 10.1108/ 01409170710823430

x. Fang, D., Chen, Y., \&Wong, L. (2006). Safety climate in construction industry: A case study in Hong Kong. Journal of Construction Engineering and Management, 132(6), 573-584.

xi. Gardner, R. O. N. (2003). Overview and characteristics of some occupational exposures and health risks on offshore oil and gas installations. Annals of Occupational Hygiene, 47(3), 201-210.

xii. ILO. (2013). The Prevention of Occupational Diseases. Retrieved March 11, 2019, from International Labour Organization website: https:/ / www ilo.org/ safework/ info/ publications/ WCMS_208226/ lang--en/ index.htm

xiii. Monday, J. M., Ekperiware, M. C., \&Muritala, B. R. (2016). Downstream Oil Deregulation And Nigerian Economy. EcoForum, 5(1), 1-25.

xiv. Mossink, J. C. M., \& de Greef, M. (2002). Inventory of socioeconomic costs of work accidents. Office for Official Publications of the European Communities.

xv. Nangih, E. (2017). Safety Practices and Performance of Oil and Gas Servicing Companies in Nigeria: Empirical Evidences from Selected Companies in Portharcourt. International Journal of Academic Research in Accounting, Finance and Management Sciences, 7(4), 177-181.

xvi. O'Dea, A., \&Flin, R. (2001). Site managers and safety leadership in the offshore oil and gas industry. Safety Science, 37(1), 39-57. https:// doi.org/ 10.1016/ S0925-7535(00)00049-7

xvii. Persaud, A. J., Kumar, U., \& Kumar, V. (2003). Innovation in the Upstream Oil and Gas Sector: A Strategic Sector of Canada's Economy. In The International Handbook on Innovation (pp. 1000-1017). https:/ / doi.org/ 10.1016/ B978-008044198-6/ 50067-X

xviii. Takala, J., Hämäläinen, P., Saarela, K. L., Yun, L. Y., Manickam, K., Jin, T. W., ... Lin, G. S. (2014). Global Estimates of the Burden of Injury and Illness at Work in 2012. Journal of Occupational and Environmental Hygiene, 11(5), 326337. https:/ / doi.org/ 10.1080/ 15459624.2013.863131

xix. Udotong, J. I. R. (2015). Air Quality Assessment at Traffic Control Points in UYO Metropolis, Nigeria. International Journal of Engineering and Technical Research (IJETR), 3(7), 325-331. 